\title{
Chemical Compositions and Nutritional Value of Moringa Oleifera Available in the Market of Mekelle
}

\author{
Teklit Gebregiorgis Amabye \\ Department of Chemistry, Mekelle University College of Natural and Computational Science, Mekelle, Tigray, Ethiopia
}

\section{Email address:}

teklitgeb@gmail.com

\section{To cite this article:}

Teklit Gebregiorgis Amabye. Chemical Compositions and Nutritional Value of Moringa Oleifera Available in the Market of Mekelle. Journal of Food and Nutrition Sciences. Vol. 3, No. 5, 2016, pp. 187-190. doi: 10.11648/j.jfns.20150305.14

\begin{abstract}
Moringaoleifera is a tree distributed in Ethiopian semiarid and coastal regions. M. oleifera is used in practice in the treatment of various diseases and is available without a medical prescription, often in the form of an herbal infusion for everyday use. The aim of the present study was to evaluate the chemical composition and nutritional values of dried M. oleifera leaf powder collected from supermarket in Mekelle. All samples of M. oleifera exhibited moisture levels varying from 3.06 to $3.34 \%$, lipids from 10.21 to $10.31 \%$, fiber from 7.29 to $9.46 \%$, ashes from 10.71 to $11.18 \%$, crude protein from 10.74 to $11.48 \%$, and carbohydrates from 54.61 to $57.61 \%$. The predominant mineral elements in the leaf powder according to ICPMS were $\mathrm{Ca}(2016.5-2620.5 \mathrm{mg} / 100 \mathrm{~g}), \mathrm{K}(1817-1845 \mathrm{mg} / 100 \mathrm{~g})$, and $\mathrm{Mg}(322.5-340.6 \mathrm{mg} / 100 \mathrm{~g})$. We concluded that $\mathrm{M}$. oleifera samples could be employed in edible and commercial applications.
\end{abstract}

Keywords: Mineral, Moringa Oleifera, Physico-Chemical

\section{Introduction}

Plants have been an important source of medicine for thousands of years. Even today, the World Health Organization (WHO) estimates that up to $80 \%$ of people still rely primarily on traditional remedies such as herbs for their medicines [1]. The medicinal value of these plants is due to the presence of a variety of phytochemicals and their elemental composition. The role of medicinal plants in disease prevention or control It is widely distributed throughout Africa, Saudi Arabia, Southeast Asia, the Caribbean Islands, and South America. Every part of M. oleifera has medicinal properties and is commercially exploitable for the development of medicinal and industrial byproducts [3].

Traditionally, the leaves, fruits, flowers, and immature pods of this tree are edible; they are used as a highly nutritive vegetable in many countries, particularly in India, Pakistan, the Philippines, Hawaii, and some African nations [4-6]. In developing nations, M. oleifera is used as an alternative to imported food supplements to treat and combat malnutrition, especially among infants and nursing mothers, by virtue of its chemical constituents [7].

Several valuable reviews of the ethno botanical uses of $M$. oleifera are available [8-11]. Moringa has been found to be a good source of polyphones and antioxidants [11].
Phytochemicals such as vanillin, omega fatty acids, and carotenoids, ascorbates, tocopherols, beta-sitosterol, moringine, kaempferol, and quercetin have been reported in its flowers, roots, fruits, and seeds. The leaves, in particular, have been found to contain phenolic and flavonoids [12, 13]; these compounds have various biological activities, including antioxidant, ant carcinogenic, immunomodulatory, antidiabetic, antiatherogenic, and heat to protective functions and the regulation of thyroid status [14-16]. Moreover, leaves contain trace elements that are essential to human health. For instance, magnesium, iron, selenium, and zinc play an important role in metabolism, and interest in these elements is increasing together with reports relating trace element status and oxidative diseases [17, 18]. However, a recent study has shown that dried M. oleifera leaves contain lead at very high values of $352.0 \mathrm{mg} / \mathrm{L}$ [19]. Therefore, it is very important to identify the mineral composition of $\mathrm{M}$. oleifera leaves that are widely consumed by humans and animals.

In Ethiopia M. oleifera is widely cultivated in different zones of the country and is found in more the in Ormia and SNNP. Few studies have been conducted on nutritional and phytochemicals composition [20,21]; however, to date, a detailed composition of the leaves of M. oleifera that is 
available in supermarket has not been reported yet. In addition, it is important to bear in mind that the mineral and phenolic contents present in leaves depend on several factors such as geographical area where the plant is cultivated, type of soil, water and fertilizers, industrialization process, and storage conditions. Taking these precedents into consideration, the aim of this study was to evaluate the phytochemicals constituents of methanol extracts and trace elements and nutritional values present in $M$. oleifera available in the supermarket of Mekelle.

\section{Materials and Methods}

A powdered form of Moringa is purchased from supermarket of Mekelle. All materials were air-dried and powdered and protected from light until further analysis.

\subsection{Proximate Composition}

The methods of the Association of Official Analytical Chemists (AOAC, 1990) were used for proximate analysis. A Moringa flour sample (5 grams) was used for determination of moisture content by weighing in crucible and drying in oven at $105^{\circ} \mathrm{C}$, until a constant weight was obtained.

Determination of ash content was done by ashing at $550^{\circ} \mathrm{C}$ for $3 \mathrm{~h}$. The Kjeldah method was used to determine the protein content. The crude fiber content of the samples was determined by digestion method and the fat was done by Soxlhet extraction method. All determinations were done in triplicate.

\subsection{Mineral Contents}

Flour sample $(0.5 \mathrm{~g})$ was weighed into a clean ceramic crucible. A blank was prepared with empty crucible. The crucible was placed in a muffle furnace at $500{ }^{\circ} \mathrm{C}$ for $4 \mathrm{hr}$. The sample was allowed to cool down in the oven after which it was removed carefully. The ashed sample was poured into already labeled $50 \mathrm{ml}$ centrifuge tube. The crucible was rinsed with $5 \mathrm{ml}$ of distilled water into the centrifuge tube. The crucible was rinsed again with $5 \mathrm{ml}$ of aquaregia. This was repeated to make a total volume of 20 $\mathrm{ml}$. The sample was mixed properly and centrifuged (IEC Centra GP8) for $10 \mathrm{~min}$ at $301.86 \mathrm{~g}$. The supernatant was decanted into clean vials for mineral determination. The absorbance was read on atomic absorption spectrophotometer (Buck Scientific Model 200A) at different wavelength for each mineral element (Zn-213.9 $\mathrm{nm}, \mathrm{Ca}-422.7 \mathrm{~nm}, \mathrm{Fe}-248.3 \mathrm{~nm}, \mathrm{Mg}-285.2 \mathrm{~nm}, \mathrm{Na}-589 \mathrm{~nm}$ and K-766.5 nm) (Novozamsky et al., 1983.

\subsection{Statistical Analysis}

All analyses were carried out in triplicates. The mean and standard deviation of the data obtained were calculated.

\section{Results and Discussion}

\subsection{Chemical Analysis}

The proximate and nutrient analyses of $M$. oleifera play a crucial role in assessing its nutritional significance $\left(<{ }^{0.05}\right)$. The proximate analysisfor the mean moisture, lipid, fiber, and ash values found in the present study are in agreement with the values reported with standard of WHO [28]. The result shows that Moringa found in the market of Mekellecontain crude protein $(10.6 \%$ ), crude fiber (about $8 \%$ ), ash (about $11 \%$ ), carbohydrates (about 56\%), moisture (about 3.2\%), and lipid (about 10.2\%). Carbohydrates are the principal sources of energy. The ash content of about $11 \%$ indicates that the leaves are rich in mineral elements. The mean protein content found in the market of Mekelle samples ranged from 10.74 to $11.48 \%$. The chemical composition values confirmed that $M$. oleifera leaves powders are an excellent food source, justifying its direct use in human nutrition or development of balanced diets for animal nutrition.

Table 1. Nutritional composition of dried M. oleifera leaf powder.

\begin{tabular}{lll}
\hline Elements & Value & WHO standard \\
\hline Moisture (\%) & $3.34 \pm 1.36$ & $7.4 \pm 2.89$ \\
Lipid (\%) & $10.31 \pm 1.2$ & $6 \pm 2.5$ \\
Ash (\%) & $7.29 \pm 0.84$ & $9 \pm 7.45$ \\
Protein (\% & $10.71 \pm 0.81$ & $24 \pm 5.8$ \\
Carbohydrates (\%) & $57.61 \pm 2.19$ & $17.6 \mathrm{~b}$ \\
Energy value $(\mathrm{Kcal} / 100 \mathrm{~g})$ & $366.2 \pm 4.23$ & $36 \pm 9.2$ \\
\hline
\end{tabular}

N.B Values are mean $\pm \mathrm{SD}$, analyzed individually in triplicate, and are expressed as $\mathrm{g} / 100 \mathrm{~g}$ leaf powder.

\subsection{Elemental Analysis}

Generally the micro nutrient of any plant depend up on the Different physical parameter of thesoils contain a particular of mineral elements qualities and quantities whose bioavailability depends on soil properties $(\mathrm{pH}$, clay and humid complex and mineralogy) [32]. Six elements, including c such as calcium and sodium was determined.

Table 2. Measured concentration in $(\mathrm{mg} / 100 \mathrm{~g})$ of trace element in the $M$. oleifera leaf powder.

\begin{tabular}{lll}
\hline Elements & Value & standard \\
\hline Calcium $(\mathrm{Ca})$ & $2016.5 \pm 22.6$ & $1897 \pm 748.4$ \\
Magnesium $(\mathrm{Mg})$ & $322.5 \pm 0.0$ & $473 \pm 429.4$ \\
Potassium $(\mathrm{K})$ & $1845 \pm 7.0$ & $1467 \pm 636.7$ \\
Sodium $(\mathrm{Na})$ & $8.13 \pm 0.6$ & $220 \pm 180$ \\
Iron $(\mathrm{Fe})$ & $19.37 \pm 6.6$ & $32.5 \pm 10.78$ \\
Zinc $(\mathrm{Zn}$ & $1.0 \pm 0.7$ & $2.4 \pm 1.12$ \\
Copper $(\mathrm{Cu})$ & $1.03 \pm 0.47$ & $0.9 \pm 0.48$ \\
\hline
\end{tabular}

Results are mean $\pm \mathrm{SD}$, analyzed individually in triplicate. Statistically significant differences between the means of both cultivars are denoted as ${ }^{* *} p<0.001 ;{ }^{*} p<0.05$

The elements were determined byatomic absorption spectrophotometer (Buck Scientific Model 200A) at different wavelengthatomic absorption of wet digestion of the dried sample with concentrated nitric acid in closed PTFE vessels 
using a microwave oven. $\mathrm{Ca}, \mathrm{Mg}, \mathrm{K}, \mathrm{Fe}$, and $\mathrm{Na}$ were present at levels of $\mathrm{mg} / 100 \mathrm{~g}$ dry matter, whereas $\mathrm{Zn}, \mathrm{Cu}$, andwere present at $\mathrm{g} / 100 \mathrm{~g}$ levels, in close agreement with levels previously reported [30], and these values fall within the ranges reported (Table 2, reference column). The elemental analysis of our samples revealed high contents of $\mathrm{Ca}$ (2016 to $2620 \mathrm{mg} / 100 \mathrm{~g}$ ), $\mathrm{Mg}$ (322 to $340.6 \mathrm{mg} / 100 \mathrm{~g}$ ), and K (1817 to $1845 \mathrm{mg} / 100 \mathrm{~g}$ ), while $\mathrm{Zn}, \mathrm{Cu}$, and Se were 1 , 1 , and 0.1 $\mathrm{mg} / 100 \mathrm{~g}$, respectively These values of $M$. oleifera samples found in Mekelle agree with those found in Burkina Faso and India [29, 30]. This sample could be recommended as a source of essential elements.

\section{Conclusion}

The result showed that the Ethiopian species of $M$. oleifera found in the market of Mekelle have nutritional potential because their leaves contain a high concentration of energy, nutrients, and minerals. Therefore, the therapeutic potential of $M$. oleifera may be due to the presence of these constituents. The presence of macro and micro elements $s$ in M. oleiferapowder appears to be within permissible limits, this suggests that quality assurance of metals are needed forplantsintendedforhumanconsumption.

\section{References}

[1] Abiodun O. A and Adepeju A.B (2011). Effect of processing on the chemical, pasting and anti-nutritional composition of Bambara nut (Vigna subterranean L. Verdc). Advance Journal of Food Science and Technology, 3(4): 224-227.

[2] Adubiaro, H. O., Olaofe, O., Akintayo, E. T. and Badalona, O. O. (2011). Chemical composition, calcium, zinc and phytate interrelationships in baobab (Adansonia digitata) seed flour. Advance Journal of Food Science and Technology, 3(4): 228232.

[3] Anjorin, T. S., P. Ikokoh and S. Okolo, 2010. Mineral composition of Moringa oleifera leaves, pods and seeds from two regions in Abuja, Nigeria. Int. J. Agric. Biol., 12: 431434.

[4] Anwar, F., S. N. Zafar and U. Rashid, 2006.Characterization of Moringa oleifera seed oil from drought and irrigated regions of Punjab. Grasasy Aceites, 57(2): 160-168.

[5] Anwar F, Latif S, Ashraf M, Gilani A. H. (2007). Moringa oleifera: a food plant with multiple medicinal uses. Phytother Res. 2007 Jan; 21(1):17-25.

[6] Arabshahi D. S., Devi D. V., Urooj A. (2007). Evaluation of antioxidant activity of some plant extracts and their heat, $\mathrm{pH}$ and storage stability. Food Chem 100:1100-1105.

[7] A. O. A. C. (1990). 15th Official methods of Analysis. Association Official Analysis Chemists, Washington D. C. USA. Pp. 807-928

[8] Compaoré, W. R., Nikièma, P. A., Bassolé, H. I. N., A. Savadogo, A., Mouecoucou, J., Hounhouigan D. J. and Traoré, S. A. (2011). Chemical Composition and Ant oxidative Properties of Seeds of Moringa oleifera and Pulps of Parkia biglobosa and Adansonia digitata Commonly used in Food Fortification in Burkina Faso. Current Research Journal of Biological Sciences 3(1): 64-72, 2011.

[9] Dairo, F. A. S. (2008). Performance and hematological evaluation of weaner rabbits fed loofah gourd seed meal (luffa cylindrica m.j.roem). AJFAND, 8(4): 451-463.

[10] Ebuehi O. A. and Avwobobe O. K. (2006). Physico-chemical and fatty acid composition of water melon (Citrillus lanatus) and melon (Colocynthis Citrillus) seed oils. Nigerian Food Journal 42(1): 25-33.

[11] FAO/WWHO (1993). Fats, oils and related product. Food standard program. Codex Aliment Arius Commission. Food and Agriculture Organization of the United Nations. World Health Organization, Rome. 8: 33-35.

[12] Ghasi S., Nwobodo E., Ofili J. O. (2000). Hypo-cholesterol emic effects of crude extract of leaf of Moringa oleifera Lam in high-fat diet fed Wistar rats. J Ethnopharmacol 69:21-5.

[13] Mabalaha, M. B., Mitei, Y. C. and Yoboah, S. O. (2007). A comparative study of the properties of selected melon seeds oils as potential candidates for development into commercial edible vegetable oil. J. Ameri. Oil Chem. Soc. 84: 31-34.

[14] Madaan, T. R. and Lai, B. M. (1984). Some studies on the chemical composition of Cucurbit kernels and their seed coats. Plant foods for Human Nutrition. 34 (2): 81-86.

[15] Makkar A. O. S. and Goodchild, A. V. (1996). Qualification of tannins. A laboratory manual. International Centre for Agriculture Research in the Dry Areas (ICARDA) Aleppo, Syria IV+. 25.

[16] Mehta L. K., Balaraman R., Amin A. H., Bafna P. A., Gulati O. D. (2003). Effect of fruits of Moringa oleifera on the lipid profile of normal and hypercholesterolemia rabbits. J Ethnopharmacol 86:191-5.

[17] Morton JF. 1991. The horseradish tree, Moringa pterigosperma (Moringaceae). A boon to arid lands. Econ. Bot. 45 (3), 318333.

[18] Novozamsky, I., Houba, V. J. G., Van, E. C. K., and Van, V. W. (1983). Plant nitrogen and phosphorus in plant tissue, novel digestion technique for multi-element. Plant analysis communication in soil science and plant analysis, 14: 239-248.

[19] National Research Council (2006). "Moringa". Lost Crops of Africa: Volume II: Vegetables. Lost Crops of Africa 2. National Academies Press. P 247.

[20] Nwinnuka, N. M., Ibeh, G. O. and Ekeke, G. I. (2005). Proximate composition and levels of some toxicants in four commonly consumed spices. Journal of Applied Sciences and Environmental Management, 9 (1):150-155.

[21] Juliani, H. R. Y. Fonseca, D. Acquaya, et.al. Nutritional assessment of Moringa (Moringaspp) from Ghana, Senegal and Zambia, Chapter 25. In: African natural plant products: Newdiscoveries and challenges in chemistry and quality. Washington, DC: American Chemical Society; 2010:469484 .

[22] 22. Kakengi, A. M. V. J. T. Kaijage, S. V. Sarwatt, etal. Effect of Moringa oleifera leafmealasa substitute for sunflower seed mealon performance of laying hens in Tanzania. Livestock Research for Rural Development. 2007; 19(8). 
[23] Kidmose, U., R.Y.Yang, S. H. Thilsted, etal. Content of carotenoids in commonly consumed Asian vegetables and stability and extractability during frying. Journal of Food Composition and Analysis. 2006; 19:562-571.

[24] Kowsalya, S., U. Chandrasekhar and R. Balasasirekha. Beta carotene retention in selected green leafy vegetables subjected todehydration.TheIndianJournalofNutritionandDietetics.2001; $38: 374$.

[25] Lockett, C. T., C. C. Calvert and L. E. Grivetti. Energy and micronutrient composition of dietary and medicinal wild plants consumed during drought. Study of rural Fulani, northeastern

Nigeria.InternationalJournalofFoodScienceandNutrition.2000; 51(3):195-208

[26] Maiga, A., D. Diallo, R. Bye and B. S. Paulsen. Determination of some toxic and essential metalions in medicinal and edible plants from Mali. Journal of. Agricultural and Food Chemistry. 2005; 53:2316-2321

[27] Makkar, H. and K. Becker. Nutrients and ant quality factors in different morphological parts of the Moringa oleifera tree. The Journal of Agricultural Science. 1997; 128:311-322.

[28] Makkar, H. P. S. and K. Becker. Nutritive value and ant nutritional components of whole and ethanol extracted Moringa oleifera leaves. Animal Feed Science and Technology. 1996; 63(1):21-228.

[29] Manh, L. H., N. N. X. Dung and T. P. Ngoi. Introduction and evaluation of Moringa oleifera for biomass production and as feed for goats in the Mekong Delta. Livestock Research for Rural Development. 2005; 17(9).

[30] Mc Burney, R. P. H., C. Griffin, A. A. Paul and D. C. Greenberg. The nutritional composition of African wild food plants: From compilation to utilization. Journal of Food Composition and Analysis. 2004; 17:277-289.

[31] Mohammed, K. A. F., L. Sarmiento-Franco, R. SantosRicaldeand J. F. Solorio Sanchez. The nutritional effect of Moringa oleifera fresh leaves as feed supplement on Rhode Island redhenegg egg production and quality. Tropical Animal Health andProduction.2012; 44:1035-1040.

[32] Nambiar, V. S. and S. Seshadri. Bioavailability trials of beta carotene from fresh and dehydrated drumstick leaves (Moringa oleifera) in a rat model. Plant Foods for Human Nutrition.2001; 56(1):83-95.
[33] Ndong, M., S. Wade, N. Dossou, et al. Nutritional value of Mor-inga oleifera, study of the bioavailability of iron and the effect of enrichment of various traditional Senegalese meals with powder of the leaves. African Journal of Food Agriculture, Nutrition, and Development. 2007; 7(3).

[34] Olugbemi, T. S., S. K. Mutayobaand F. P. Lekule. Effect of moringa (Moringa oleifera) inclusion in cassava based diets fed to broiler chickens. International Journal of Poultry Science.2010; 9(4):363-367.

[35] Radek, M. and G.P. Savage. Oxalates in some Indian green leafy vegetables. International Journal of Food Sciences and Nutrition. 2008; 59(3):246-260.

[36] Rajyalakshmi, K., K. Venkatalaxmi, Y. Venkatalakshmamma, etal. Totalcarotenoid and beta-carotene contents of forest green leafy vegetables consumed by tribal's of south India. Plant Foods for Human Nutrition. 2001; 56:225-238.

[37] Sanchez Machado, D., J. Nunez Gastelum, C. Reyes Moreno, etal. Nutritional quality of edible parts of Moringa oleifera. Food Analytical Methods. 2010; 3:175-180.

[38] Sanchez-Machado, D.I., J. Lopez-Cervantes and N. J. R. Vazquez. High-performance liquid chromatography method tomeasure alpha and gamma tocopherol in leaves flowers and fresh beans from Moringa oleifera. Journal of ChromatographyA.2006; 1105:111-114.

[39] Satawase, A. N., G. R. Pandhre, P. G. Sirsat and Y. R. Wade. Studies on drying characteristic and nutritional composition of drum stick leaves by using sun, shadow, cabinet and oven drying methods. Open Access Scientific Reports. 2013; 2(1).http://dx.doi.org/10.4172/scientificreports.584 accessed March2013.

[40] Yahaya Ahmed Iyaka, Suleiman Idris, Rahmatallah Adenike Alawode, Bello Usman Bagudo, Nutrient Content of Selected Edible Leafy Vegetables, American Journal of Applied Chemistry. Vol. 2, No. 3, 2014, pp. 42-45. doe: 10.11648/j.ajac.20140203.12

[41] .Adegun Maria Kikelomo. Voluntary Feed Intake and Nutrient Utilization of West African Dwarf Sheep Fed Supplements of Moringa oleiferaand Gliricidia sepiumFodders. American Journal of Agriculture and Forestry. Vol. 2, No. 3, 2014, pp. 94-99. doi: 10.11648/j.ajaf.20140203.16. 